\title{
SIGHTING OF A PROTHONOTARY WARBLER IN REGINA
}

by D. G. Bobbitt, 2834 23rd Avenue, Regina

On May 17, 1969, Fr. H. B. Bedard, S.J., and I were patrolling the northwest corner of the Legislative Grounds for the annual Regina May bird census when we sighted a male Prothonotary Warbler (Protonotaria citrea) in full spring plumage. At approximately 7:30 a.m. when we were checking a Green Ash for a suspected Baltimore Oriole, I noticed a small, warbler-sized hird preening itself on a branch. It had a very bright yelloworange head and chest, and what seemed to be a completely greyish body. When I pointed it out to Fr. Bedard, he immediately identified it as a Prothonotary, a bird with which he was familiar from the eastern United States. A check with Peterson's Field guide to the birds and the Birds of North America by Robbins, Bruun, Zim and Singer showed the three field marks we had noticed-the golden head and chest, dark greyish body and wings without wing bars, and white outer edges of the tailwhich together indicated the Prothonotary-a bird that couldn't be mistaken for any other.

The Warbler soon flew from the tree to the edge of the lake, giving us a better view of it. It made several trips from tree to lake, where it moved around at the water's edge. As Fr. Bedard went to get Dr. Jim Jowsey and the rest of our May Day count group, I continued observing the Prothonotary which darted across a corner of the lake to some waterside slabs of concrete by the Albert Street Bridge, after which it winged back to our side of the lake, landing in a tree. Soon after this I lost it.

That evening at six o'clock I resighted the Prothonotary at the southeast corner of the lake, across the road from the Diefenbaker Homestead. Again I found the bird in trees near the water's edge, and also I verified the three main field marks.
How the "Golden Swamp Warbler", as it is sometimes called, came to be in Regina poses an interesting question. The normal range of the species lies far to the south and east, the northern limits of its usual range being southern Minnesota and Michigan. Eastern Nebraska would seem to be the farthest western extreme. The only spots in Canada where it has been found are Ontario, where it breeds sparingly in the extreme southern sections, and New Brunswick and Nova Scotia, where it is recorded as being casual. As far as I know there are no previous records for Sakatchewan.

There was no noticeable wave of warblers that day nor were there any especially strong winds from the south the previous night. How this bird came to be here seems therefore hard to explain.

\section{SONG SPARROWS HAWKING MAYFLIES}

by Al Grass, 5666 Rumble St., Burnaby 1, B.C.

On June 12, 1969, at E. C. Manning Park, B.C., three Song Sparrows (Melospiza melodia) were observed hawking Mayflies (Ephemeroptera) in a manner similar to flycatchers and waxwings. Each bird waited on the limb of a tree about 18 to 24 inches above the water's surface until an insect came within close proximity. Then the bird quickly darted out, snatching the mayfly from mid-air. All observations were made using $7 \times 35$ binoculars at a distance of about 20 feet. It could be clearly seen that the birds were accurate in their hunting, since at no time during the 15-minute observation period were they observed to miss a "strike".

I could find no specific reference in the literature to Song Sparrows hawking mayflies. 